\title{
Authors reply: Prevention of the SPREAD OF INFECTION - THE NEED FOR A FAMILY-CENTRED APPROACH TO HYGIENE PROMOTION
}

\author{
S Bloomfield (sallyfbloomfield@aol.com)1,2, M Exner ${ }^{1,3}$, G M Fara ${ }^{1,4}$, E A Scott S $^{1,5}$ \\ 1. International Scientific Forum on Home Hygiene, Cheshire, United Kingdom \\ 2. London School of Hygiene and Tropical Medicine, London, United Kingdom \\ 3. Institute for Hygiene and Public Health, University of Bonn, Bonn, Germany \\ 4. Department Public Health Sciences G. Sanarelli, Città Universitaria, Rome, Italy \\ 5. Simmons College, Boston, United States
}

We thank Kevin G. J. Pollock, Rod House and John M. Cowden for their response to our article 'Prevention of the spread of infection the need for a family-centred approach to hygiene promotion' [1].

We agree that promulgating the hygiene hypothesis and related environmental issues to the public can serve to confuse, rather than to inform. The reality is however that these issues have already received widespread coverage by the media, which tends to leave the public concerned and confused about the role of hygiene and cleanliness, particularly in relation to the functioning of the immune system. Although there is good evidence that microbial exposure in early childhood may help to protect against allergies, there is no evidence that we need exposure to harmful microbes or that we need to suffer a clinical infection [2]. There is also no evidence to show that reduced exposure to pathogens through hygiene measures such as handwashing, food hygiene etc. is linked to increased susceptibility to atopic disease [3]. To rectify the confusion, we need clearer communication with the public on these complex issues which includes emphasising the important role of 'hygiene' (the things we do to protect us from exposure to harmful microbes) and what hygiene means. In the risk perception of people, it is important that the 'hygiene hypothesis' is not used as an argument against implementing basic hygiene requirements in home, community and also in hospital settings.

As far as legionella is concerned there is some evidence that transmission can occur in the home as well as in public places, although we did not imply that this is through person-to-person contact, and we agree that it is important not to over-emphasise the risk in consumer advice communications. In August and September 2006, eight cases were reported to a local health authority in eastern England. No common source for this cluster could be established. Legionella was isolated from the home of two patients (two showerheads in one home and a hot tub in the other), although clinical isolates were not available for genetic typing. The investigators concluded that multiple sources (both domestic and environmental) may have caused the cluster [4]. In Germany, $47 \%$ of notified legionella Infections are estimated to be acquired at home [5]. The 'home hygiene' measure which the International Scientific Forum on Home Hygiene recommends to avoid the possibility of inhalation of pathogens such as legionella or pseudomonas which may become associated with showerheads, is to turn the hot water on full and allow it to flow for a while to create a flushing process before taking the first shower after an interval of no use [6]. This is particularly important in homes where there are family members who may be immuno-compromised.

\section{References}

1. Bloomfield S, Exner M, Fara GM, Scott EA. Prevention of the spread of infection - the need for a family-centred approach to hygiene promotion. Euro Surveill. 2008;13(22):pii=18889. Available from: http://www.eurosurveillance.org/ ViewArticle.aspx?ArticleId $=18889$

2. Bremner SA, Carey IM, DeWilde S, Richards N, Maier WC, Hilton SR, et al. Infections presenting for clinical care in early life and later risk of hay fever in two UK birth cohorts. Allergy. 2008 Mar;63(3):274-83.

3. Bloomfield SF, Stanwell-Smith R, Crevel RWR, Pickup J. Too clean, or not too clean: the Hygiene Hypothesis and home hygiene. Clin Exp Allergy. 2006; 36(4):402-25.

4. Pereira AJ, Broadbent J, Mahgoub H, Morgan O, Bracebridge S, Reacher M, et al. Legionnaires' disease: when an 'outbreak' is not an outbreak. Euro Surveill. 2006;11(48):pij=3089. Available from: http://www.eurosurveillance. org/ViewArticle. aspx?ArticleId $=3089$

5. Robert Koch Institute. Legionellose im Jahr 2006. Epidemiologisches Bulletin 2007:50:469-73. Available from: http://www.rki.de/cln_100/nn 264978/DE/ Content/Infekt/EpidBull/Archiv/2007/50_07,templateId=raw,property=public ationFile.pdf/ 50_07.pdf

6. International Scientific Forum on Home Hygiene. Recommendations for selection of suitable hygiene procedures for use in the domestic environment. Available from: http://www.ifh-homehygiene.org/2public/2pub04.htm

This article was published on 5 June 2008.

Citation style for this article: Bloomfield S, Exner M, Fara GM, Scott EA. Authors reply: Prevention of the spread of infection - the need for a family-centred approach to hygiene promotion. Euro Surveill. 2008;13(23):pii=18894. Available online: http://www. eurosurveillance.org/ViewArticle.aspx?ArticleId=18894 